\title{
PERUBAHAN SOSIAL BUDAYA MASYARAKAT DI SEKITAR KAWASAN WISATA PULO CINTA ECO RESORT
}

\author{
Annisa Rizqa Alamri \\ Fakultas Ilmu Sosial dan Ilmu Politik, Universitas Gorontalo \\ Email: daffiannisa@gmail.com \\ Yayan Hanapi \\ Fakultas Hukum, Universitas Gorontalo \\ Email: yayanhanapi@gmail.com
}

\begin{abstract}
A meeting between the local community and tourists will produce some social changes in the local community where tourist site is located. The present study describes forms of socio-cultural changes in the local communities since the formation of Pulo Cinta Eco Resort for four years. The purpose of the present study was to examine the forms of socio-cultural changes in Patoameme Village community after the development of Pulo Cinta Eco Resort. The research method was case study using descriptive approach. This was based on the issues, which were what the object was and how it was formed. The data collection used observation, in-depth interview, and document study. The data was analyzed by performing data reduction, display and conclusion drawing. The data validity was examined using data source triangulation technique. Based on the findings in the field, the socio-cultural changes were; 1) symbols, b) language, c) values and d) norms.
\end{abstract}

Keywords: Social Cultural Changes, Develepoment of Tourist Areas, Local Community

\section{Pendahuluan}

Pariwisata saat ini telah menjadi salah satu tolak ukur pembangunan. Pesatnya perkembangan kawasan wisata saat ini telah tersebar di daerah- daerah di Indonesia, mengingat hampir seluruh daerah di Indonesia memiliki potensi wisata dan daya tarik yang sangat mumpuni untuk dikembangkan. Industri pariwisata yang baru hadir ditengah masyarakat dapat dipastikan membawa perubahan dalam kelompok masyarakat tersebut, baik perubahan pada kehidupan, tingkat kesejahteraan sosial 
dan juga kebudayaan. Adanya kawasan wisata baru juga dapat menjadi wadah atau alat bagi masyarakat untuk memperkanalkan kebudayaan mereka dan atau mengenal kebiasaan-kebiasaan baru dari wisatawan yang berkunjung, yang kemungkinan besar berbeda dengan kebiasaan masyarakat lokal.

Pertemuan antara masyarakat lokal dengan para wisawatan yang masing masing memiliki latar belakang sosial budaya yang berbeda maka dapat dipastikan akan menghasilkan beberapa bentuk perubahan sosial di dalam masyarakat lokal itu sendiri. Semua perubahan besar yang terjadi di dalam masyarakat mencakup perubahan sosial budaya. Perubahan sosial budaya sendiri dipandang sebagai proses di mana terjadi perubahan struktur masyatakat yang selalu berjalan sejajar dengan perubahan kebudayaan dan fungsi suatu sistem sosial (Ranjabar Jacobus, 2015). Lokasi pariwisata sadalah sebuah akibat yang sangat jelas mendorong adanya perubahan pada struktur sosial yang didukung oleh nilai dan norma-norma kebudayaan setempat. Provinsi Gorontalo sebagai salah satu daerah dengan berbagai potensi alam yang mumpuni juga telah mengembangkan berbagai potensi wisata sejak tahun 2010. Potensi wisata yang sebelumnya belum dikembangkan kini mulai dibangun sebagai salah satu roda perekonomian baru di Provinsi Gorontalo. Salah satu lokasi pariwisata yang saat ini tengah berkembang dan digemari oleh wisatawan adalah Pulo Cinta Eco Resort.

Pulo Cinta Eco Resort adalah Resort Cottage yang berada di tengah laut dan sudah mulai didirikan sejak tahun 2014, yang merupakan kerja sama antara Pemerintah Kabupaten Boalemo. Pulo cinta sendiri terletak di Desa Patoameme, Kecamatan Botumoito, Kabupaten Boalemo. Pada tahun 2016, Pulo cinta selesai dibangun dan siap menerima kunjungan wisatawan. jarak Pulo Cinta sendiri dari pusat Kota Gorontalo adalah 115 KM atau sekitar 3 jam menggunakan mobil. 


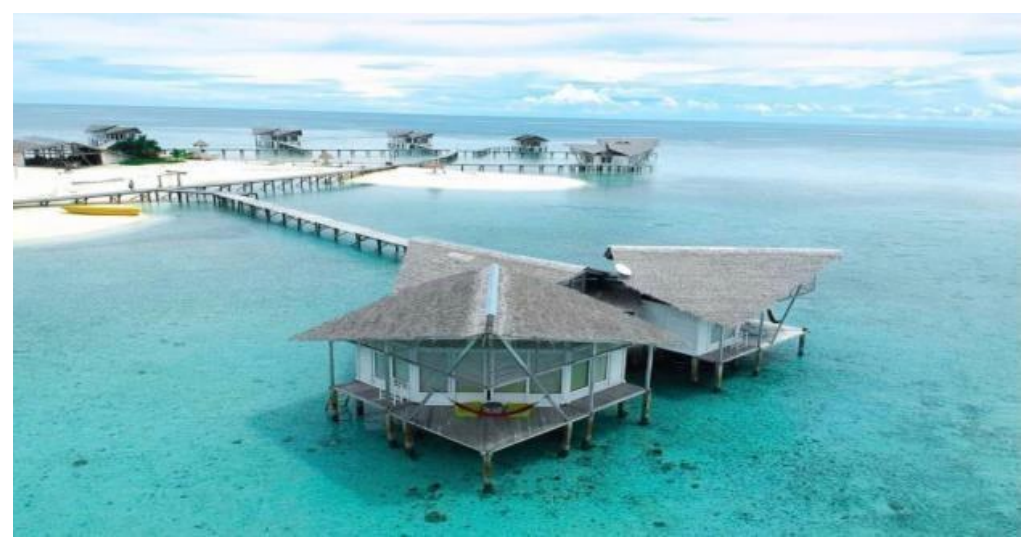

Gambar 1. Pulo Cinta Eco Resort

Sumber: Management Pulo Cinta 2020

Gambar diatas adalah Pulo Cinta Eco Resort Jika dilihat dari atas menguunakan Drone. Desa tempat lokasi Pulo Cinta berada adalah Desa Patoameme dengan jumlah penduduk yaitu 2203 orang. Masyarakat Desa Patoameme adalah penduduk lokal yang paling mungkin terdampak oleh perubahan sosial dan budaya pasca adanya Pulo Cinta Eco Resort, hal tersebut dikarenakan sebelumnya di Desa Patoameme tidak memiliki aktivitas kepariwisataan.

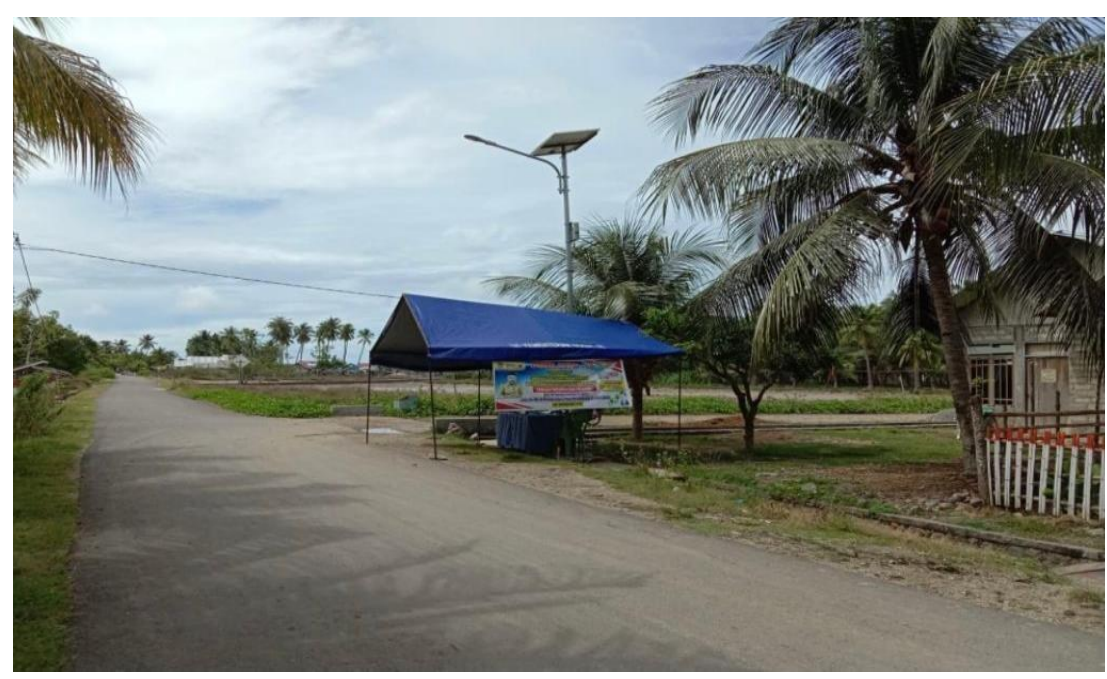

Gambar 2. Desa Patoameme

Sumber: Dokumentasi Peneliti 2020 
Dari gambar diatas terlihat keadaan Desa Masyarakat Lokal yaitu Desa Patoameme, dimana setiap wisatawan yang hendak ke pulo Cinta akan melewati Desa Patoameme kemudian menuju ke Dermaga Desa Patoameme. Target wisatawan utama dari Pulo Cinta sendiri adalah $80 \%$ wisatawan asing dan 20\% wisatawan nasional. Banyaknya kunjungan wisatawan tersebut selama kurang lebih 4 tahun belakangan ini memungkinkan terjadinya perubahan sosial budaya masyarakat lokal. Sebelum adanya Kawasan wisata Pulo Cinta, masyarakat lokal rata-rata emiliki mata pencaharian sebagai nelayan. Desa Patoameme juga dikenal sebagai salah satu desa nelayan di Kabupaten Boalemo.

Perubahan sosial budaya yang terjadi pada masyarakat lokal dapat menimbulkan dampak posistif dan dampak negatif. Dampak posistif berupa terciptanya masyarakat yang dinamis dandampak negative yaitu munculnya berbagai masalah sosial (Murdiyatmoko dalam (Gunawan et al., 2015). Didasarkan pada dampak yang akan ditimbulkan dari perubahan sosial budaya akibat adanya kawasan wisata Pulo Cinta Eco Resort maka artikel ini akan menguraikan apa saja bentuk-bentuk perubahan sosial budaya masyarakat lokal terhadap adanya kawasan wisata Pulo Cinta Eco Resort yang sudah hadir ditengah masyarakat selama empat tahun. Selain itu, artikel ini mengusulkan rekomendasi bagaimana tindakan yang dapat diambil oleh pemangku kepentingan, yaitu pihak pengembang pulo cinta dan juga Pemerintah Kabupaten Boalemo kedepannya untuk lebih peka lagi dan agar pemangku kepentingan ini dapat mempersiapkan resiliensi bagi perubahan sosial budaya yang muncul pasca adanya Pulo Cinta Eco Resort. Kajian mengenai perubahan sosial budaya masyarakat di sekitar kawasan wisata pulo cinta eco resort diharapkan dapat memberikan gambaran terkait kondisi serta bentuk-bentuk perubahan sosial budaya yang terjadi kepada pihak-pihak yang terlibat didalamnya, serta diharapkan rekomedasi yang disusun dalam artikel ini dapat dijadikan masukan bagi perumusan kebijakan yang akan diambil dikemudian hari. 


\section{Kerangka Pikir}

\section{Landasan Teori dan Konsep}

Kawasan Pariwisata

Pariwisata memiliki pengertian berupa perjalanan dari satu tempat ke tempat lain, bersifat sementara dilakukan perorangan maupun kelompok, sebagai usaha mencari keseimbangan atau keserasian dan kebahagiaan dengan lingkungan hidup dalam dimensi sosial, budaya, alam dan ilmu. Oleh karena itu sata ini terdapat banyak sekali kawasan pariwisata yang dikembangkan. Pengembangan kawasan wisata yang terus-menerus dilakukan akan berdampak pada kehidupan masyarakat di skeitar kawasan wisata dan menyebabkan adanya perubahan sosial maupun budaya pada keseharian masyarakatnya (Anandhyta, 2020). Lokasi atau kawasan pariwisata merupakan potensi strategis dalam mendorong perekonomian Indonesia hingga kemudian dapat mengambil bagian dari kemajuan perekonomian. Terjadinya sirkulasi 3T, transportasi, telekomunikasi, dan tourism atau pariwisata, memperlihatkan dimana kegiatan pariwisata sudah berhasil menjadi faktor yang mendorong kekuatan yang telah memacu koalisi dunia di dalam integrasi ekonomi dan mobilitas manusia lintas daerah hingga lintas Negara (Rusman dalam Nyamwanza, 2014).

Pada aturan Undang-undang No. 10 Tahun 2009 terkait kepariwisataan, dijelaskan dimana penyelenggaraan pariwisata berasaskan manfaat, kemandirian, partisipatif, kelestarian dan berkelanjutan, dimana tujuan dari kepariwisataan dijelaskan untuk peningkatan perkembangan ekonomi, peningkatan kesejahteraan sosial masyarakat, menghilangkan kemiskinan, mengurangi pengangguran, menjaga dan memperbaiki lingkungan sumber daya alam, serta juga mempresentasikan kebudayaan. Dengan ideology tersebut maka dapat disimpulkan bahwa dalam kepariwisataan harus memelihara dan juga menjaga hubungan dengan lingkungan 
juga pemberdayaan bagi masyarakat lokal tempat dimana kawasan wisata tersebut berada.

Pariwisata dan masyarakat (manusia) saling berkaitan satu sama lain. Manusia menjadikan aktivitas pariwisata sebagai suatu kebutuhan, sebaliknya pariwisata tidak dapat berlajan tanpa aktifitas kepariwisataan oleh manusia di suatu destinasi (Junaid, 2020) berdasarkan hal tersebut dapat disimpulkan bahwa kawasan pariwisata adalah sebuah lokasi yang dijadikan potensi bagi peningkatan kesejahteraan masyarakat lokal yang membutuhkan simbiosis mutualisme antara manusia, alam dan juga kebudayaan setempat, agar adanya kawasan wisata tidak membawa dampak negative dari perubahan-perubahan yang terjadi di mastarakat.

\section{Perubahan Sosial budaya}

Pengembangan kawasan pariwisata menjadi salah satu faktor pemicu adanya perubahan sosial budaya didalam sebuah masyarakat. Perubahan yang terjadi karena adanya perkembangan kawasan wisata dapat mengarah pada perubahan keadaan sosial dan kebudayaan masyarakat tempat dimana lokasi parwisata tersebut berada. Perubahan terbentuk bersamaan dengan asas dan sifat dasar alamiah dari manusia yang senantiasa terus melakukan perubahan, karena manusia mempunyai dan memiliki karakter yang selalu tidak mudah puas dengan apa yang telah dimiliki, pada harfiahnya manusia selalu ingin mencari sesuatu yang baru hingga mampu untuk mengubah keadaan sehingga menjadi lebih baik dan juga sesuai dengan hajat dan kepentingannya. Dengan mempunyai landasan aka pikiran, maka manusia mempunyai 7 keahlian yang dapat berfungsi untuk: membuat, merombak, memperlakukan, menatakembali, 4 memperindah, mengembangkan, dan juga memaksimalkan semua upaya dalam hal dalam interaksinya dengan alam semesta maupun dengan manusia yang lainnya (Herimanto dan Winarno, 2009) tujuh keahlian tersebut adalah potensi yang dipunyai oleh manusia untuk keperluannya di 
dalam usaha untuk mewujudkan keperluan hidupnya, yaitu adalah untuk mempertahankan dan menambah derajat kehidupannya sebagai seorang manusia, menambah sisi kemanusiaannya, dengan upaya menciptakan peradaban. Perubahan sosial adalah bagian dari perubahan peradaban dan juga budaya. Perubahan yang besar termasuk sisi sosial budaya (Kingsley Davis dalam Soerjono Soekanto, 2000).

Selain itu, istilah tersebut biasanya selalu ditukar gunakan; yaitu, digunakan ungkapan perubahan sosial - budaya (sosio cultural change) sehingga dapat mencakup dua jenis perubahan yang dimaksud (Hunt, 1992) perubahan sosial dan kebudayaan memiliki satu sisi yang sama dimana keduanya memiliki hubungan dengan suatu penerimaan sebagai perbaikan dalam cara masyarakat untuk mencukupi kebutuhannya. Terjadinya perubahan sosial budaya dapat diartikan karena adanya ketidakmiripan dari unsur-unsur sosial yang bisa jadi bertolak belakang dengan kehidupan masyarakat. Perubahan sosial yang dibahas dalam tulisan ini mencakup perubahan dalam nilai sosial, norma, kelompok sosial, interaksi sosial, pola- pola perilaku, serta segi kehidupan masyarakat lokal setempat.

\section{Metode Penelitian}

Penelitian ini menggunakan metode studi kasus (case study) yang menggunakan pendekatan deskriptif, hal ini berdasarkan pada kasus atau permasalahan yang diangkat yaitu tentang apa dan bagaimana objek tersebut terbentuk. Penelitian ini memusatkan diri secara intensif pada satu obyek tertentu yang mempelajarinya sebagai suatu kasus. Data studi kasus dapat diperoleh dari semua pihak yang bersangkutan, dengan kata lain dalam studi ini dikumpulkan dari berbagai sumber (Hadari, Nawawi. 2003). Dengan menggunakan pendekatan deskriprif studi kasus berupa penggambaran tentang perubahan sosial budaya masyarakat lokal pasca adanya Pulo Cinta Eco Resort yang secara nyata menyangku beberapa hal sebagai berikut: a) fokus pada masalah perubahan sosial budaya 
masyarakat lokal, b) melihat hubungan sebab akibat, c) melihat dari berbagai bukti yang ada dilapangan. Metode penelitian studi kasus merupakan startegi yang tepat untuk digunakan dalam penelitian how atau why, fokus penelitiannya adalah untuk melacak peristiwa yang telah terjadi (Yin, R. K. 2009). Pada lokasi eksplorasinya, studi kasus dibatasi pada wilayah mikro, karena lebih difokuskan untuk mengkaji individun kelompok, lembaga dan juga organisasi. Masalah yang diangkat juga diberikan batasan pada kasus dan fokus hingga wkatu tertentu. Studi kasus adalah penelitian yang mengeksplorasi secara mendalam suatu program, suatu peristiwa, sebuah proses, atau satu atau lebih individu (Creswell, 2013).

Data yang digunakan sebagai sumber dasar hasil analisis dalam penelitian ini adalah dengan menggunakan teknik pengumpulan data wawnacara mendalam, dokumentasi dan juga observasi. Data yang kemudian diperoleh diolah dalam tiga tahapan yakni reduksi data, penyajian data dan penarikan kesimpulan (Creswell, 2013). Setelah data diperoleh maka dilakukan pengujian keabsahan data menggunakan teknik triangulasi (Mudja Raharjo, 2017).

\section{Hasil Penelitian}

\section{Keadaan Masyarakat Lokal Sebelum Adanya Pulo Cinta Eco Resort}

Keadaan masyarakat Desa Patoameme atau masyarakat lokal sebelum adanya Pembangunan Kawasan pulo cinta Eco Resort dapat dilihat melalui beberapa hal dibawah ini:

1. Mayoritas bermata pencaharian sebagai nelayan (sebesar $75 \%$ )

2. Mata pencaharian lain selain nelayan adalah bidan, perawat, dukun kampung terlatih dan sebesar 22,59\% belum bekerja

3. Rendahnya tingkat pendidikan masyarakat

4. Rendahnya pemahaman terhadap bahasa asing 
5. Bahasa yang sepenuhnya menggunakan bahasa lokal yakni bahasa Gorontalo

6. Belum menggunakan smartphone

7. Interaksi sosial antara stakeholder yang kuat dengan masyarakat dan juga LSM setempat

8. Berpegangan pada norma sosial dan norma-norma keagamaan

9. Masyarakat yang masih sangat tertutup

10. Minimnya pemahaman masyarakat terhadap pemanfaatan Potensi Sumber yang ada di lingkungan mereka.

\section{Perubahan Sosial Budaya Masyarakat Lokal Desa Patoameme Setelah Adanya Pulo Cinta Eco Resort}

Pulo Cinta sendiri mulai dibangun sejak tahun 2014, dan mulai beroperasi atau mulai menerima wisatawan sejak Bulan Maret 2016. Sejak saat itu masyarakat lokal yang semua mayoritas bekerja sebagai nelayan, maka mulai beralih profesi menjadi pengemudi taksi perahu dan bekerja sebagai staff di Pulo Cinta, seperti yang terlihat pada tabeldibawah ini:

Tabel 1. Jenis pekerjaan Masyarakat di Desa Patoameme tahun 2013

\begin{tabular}{lc}
\hline \multicolumn{1}{c}{ Jenis Pekerjaan } & Jumlah (Orang) \\
\hline 1. Nelayan & 156 \\
2. Bidan & 2 \\
3. Perawat & 1 \\
4. Dukun kampung terlatih & 2 \\
5. Belum bekerja & 47
\end{tabular}

Sumber: Data Kantor Desa Patoameme Tahun 2013 
Tabel 2. Jenis Pekerjaan Masyarakat di Desa Patoameme Tahun 2019

\begin{tabular}{lc}
\hline \multicolumn{1}{c}{ Jenis Pekerjaan } & Jumlah (Orang) \\
\hline 1. Nelayan & 63 \\
2. Staff/ pegawai di Pulo Cinta & 35 \\
3. Bidan & 3 \\
4. Perawat & 2 \\
5. Dukun kampung terlatih & 7 \\
6. Pengusaha Warung & 6 \\
7. Belum Bekerja & 2 \\
8. Pengusaha loundry & 110 \\
9. Taksi Perahu & \\
\hline
\end{tabular}

Sumber: Data Kantor Desa Patoameme Tahun 2019

Dari kedua tabel diatas terlihat bahwa terdapat jelas dua perbedaan antara kedua tabel. Pada tabel pertama terlihat bahwa menjadi nelatyan masih menjadi sumber mata pencaharian utama di Desa Patoameme, sementara pada tabel kedua terlihat bahwa masyrakat sudah tidak menjadikan nelayan sebagai pekerjaan utama. Sejumlah nelayan mulai beralih menjadi taksi perahu, yang mengantarkan wisatawan ke Pulo cinta. 


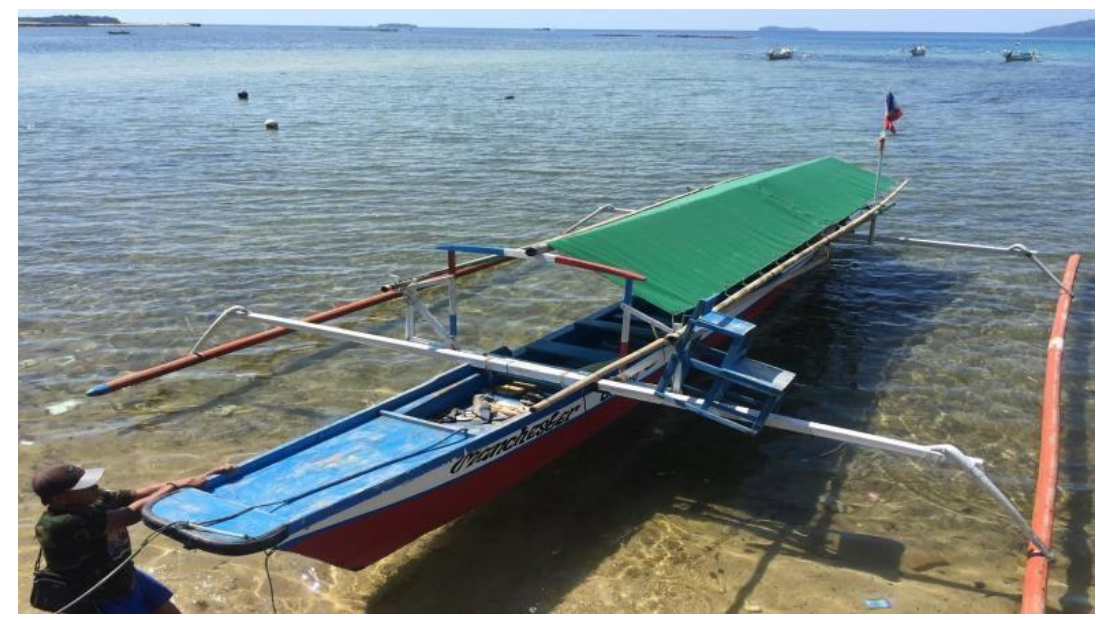

Gambar 3. Taksi Perahu oleh masyarakat yang hendak ke Pulo Cinta Sumber: Dokumentasi Peneliti 2020

Perahu yang disediakan oleh masyarkat lokal adalah perahu yang digunakan bagi wisatawan yang hendak pulang-pergi atau tidak menginap di Pulo Cinta, sementara bagi wisatawan yang sudah melakukan booking untuk kedatangan ke Pulo Cinta melalui website untuk perahunya sudah disediakan oleh pihak Pulo Cinta dengan penegmudinya juga berasal dari masyarakat lokal Desa Patoameme. Dalam rentan waktu 4 tahun juga sejak adanya Pulo Cinta, terdapat beberapa jenis pekerjaan baru bagi masyarakat Desa Patoameme, yaitu 35 orang masyarakat menjadi staf di Pulo Cinta. Sejak adanya kawasan wisata Pulo Cinta, juga terdapat jenis usaha baru yang dikembangkan masyarakat yaitu usaha loundry, terdapat dua orang masyarakat Desa Patoameme yang mengembangkan usaha londry kemudian bekerja sama dengan pihak Pulo Cinta. Sejak adanya Pulo Cinta, angka pengangguran di Desa Patoameme juga menurun drastis dengan adanya berbagai macam sumber mata pencaharian baru. Masyarakat Lokal Patoameme juga semakin sadar akan pentingnya tingkat pendidikan. Hal ini di dasari oleh keinginan mereka untuk dapat di rekrut dan bekerja di Pulo Cinta Eco Resort, karena syarat utama bekerja sebagai staf biasa di Pulo Cinta adalah minimal berijazah SMA. Dorongan untuk memiliki kehidupan yang lebih baik mendasari alasan masyarakat untuk bekerja di Pulo Cinta, upah yang 
ditawarkan berkisar antara Rp. 2.500.000-5.000.000 tergantung dari lama bekerja dan tanggung jawab atau jabatan yang diemban. Berikut tingkat pendidikan masyarakat lokal patoameme sebelum dan setelah adanya pengembangan kawasan wisata pulo cinta eco resort.

Tabel 3. Tingkat pendidikan masyarakat Desa Patoameme Tahun 2013

\begin{tabular}{lll}
\hline No & \multicolumn{1}{c}{ Tingkat Pendidikan } & Jumlah \\
\hline 1 & Tidak/Belum Tamat SD & 77 \\
2 & Tamat SD & 63 \\
3 & Tamat SMP & 52 \\
4. & Tamat SMA & 13 \\
5. & Tamat Diploma, S2, S2, dan S3 & 3 \\
\hline
\end{tabular}

Sumber: Data Kantor Desa Patoameme Tahun 2013

Tabel 4. Tingkat pendidikan masyarakat Desa Patoameme Tahun 2019

\begin{tabular}{llc}
\hline No & \multicolumn{1}{c}{ Tingkat Pendidikan } & Jumlah \\
\hline 1 & Tidak/Belum Tamat SD & 30 \\
2 & Tamat SD & 79 \\
3 & Tamat SMP & 72 \\
4. & Tamat SMA & 44 \\
5. & Tamat Diploma, S2, S2, dan S3 & 6 \\
\hline
\end{tabular}

Sumber: Data Kantor Desa Patoameme Tahun 2019 
Dari tabel diatas dapat terlihat bahwa adanya peningkatan pada kesadaran masyarakat akan pendidikan. Terdapat peningkatan yang cukup signifikan dalam kurun waktu 4 tahun sejak adanaya Pulo Cinta Eco Resort.

Perubahan yang muncul setelah adanya Pengembangan Kawasan Wisata Pulo Cinta Eco Resort yang kurang lebih sudah berjalan 4 tahun belakangan ini yaitu:

1. Mayoritas masyarakat lokal beralih mata pencaharian sebagai tasksi perahu (110 org)

2. Adanya mata pencaharian baru yaitu usaha laundry, pengusaha warung, staf Pulo Cinta dan juga taksi perahu

3. Meningkatnya tingkat kesadaran masyarakat akan pendidikan, dikarenakan kebutuhan mereka untuk memenuhi biaya hidup dan para orang tua sudah memiliki pekerjaan tambahan sejak adanay Pulo cinta eco resort sehingga mampu untuk menyekolahkan anaknya.

4. Munculnya kesadaran masyarakat akan pentingnya memahami dan mempelajari bahasa asing, dalam hal ini bahasa inggris. Pihak pulo cinta memberika pelatihan kepada staff, pengemudi taksi perahu hingga masyarkat lokal yang ingin belajar bahasa inggris, fasilitas ini disediakan oleh pihak Pulo Cinta Eco resort.

5. Bahasa yang digunakan oleh masyarakat setempat jika berkomunikasi dengan wisatawan domestic dari luar Gorontalo sudah menggunakan bahasa Indonesia baku.

6. Masyarakat lokal, khususnya staff pulo Cinta dan para taksi perahu sudah mengenal smartphone. Hal ini dikarenakan sejak adanya Pulo Cinta, tower untung jaringan $3 \mathrm{G}$ dan $4 \mathrm{G}$ sudah ada.

7. Adanya konflik antara stakeholder dan Pihak LSM. Hal ini karena beberapa oknum dari pihak LSM lokal tidak menerima adanya kawasan wisata Pulo Cinta 
8. Masyarakat tua masih melakukan ritual keagamaan, meskipun masih susah menerimacara berpakaian para wisatawan asing yang menurut mereka berbeda dnegan norma sosial yang dianut. Berbeda dengan masyarakat tua, masyarakat lokal yang muda dengan rentan usia 17-35 Tahun sudah sangat bisa menerima dan memaklumi cara berpakaian para wisatawan asing. Hal ini yang kemudian membuat adanya pergeseran norma sosial di masyarakat lokal.

9. Masyarakat yang sudah sangat terbuka dengan orang asing atau wisatawan yang hendak ke pulo cinta

10. Adanya pemahaman masyarakat tentang pemanfaatan potensi sumber demi memperbaiki taraf kehidupan, seperti ibu-ibu PKK yang membuat kerajinan seperti kotak tisu dan gantungan kunci untuk kemudian di jual di Pulo Cinta sebagai souvenir.

\section{Output yang diperoleh dari adanya perubahan sosial masyarakat lokal pasca adanya pengembangan kawasan wisata Pulo Cinta Eco Resort}

1. Output Positif

1. Dibangunnya jembatan di Dermaga Desa Patoameme

2. Mengangkat nama Gorontalo di kancah Internasional

3. Tersedianya lapangan pekerjaan baru

4. Meningkatkan pemahaman masyarakat terkait pendidikan, bahasa dan penggunaan smartphone. 


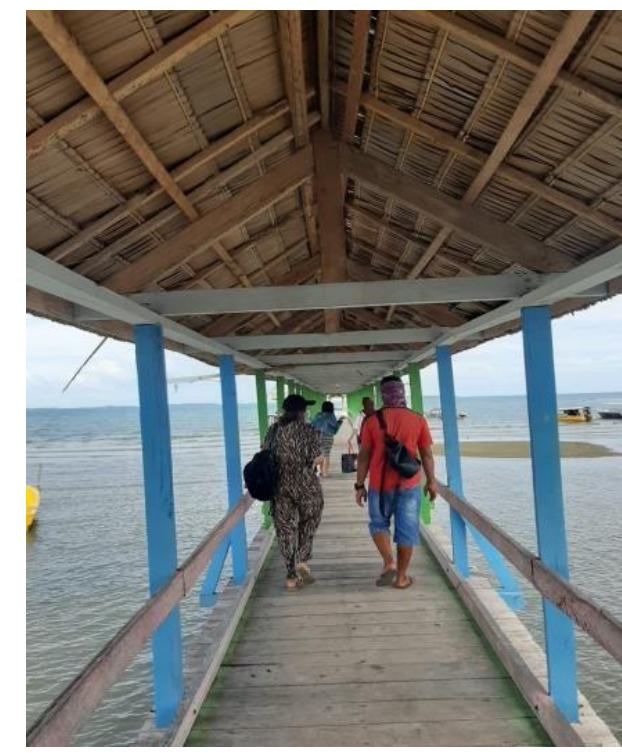

Gambar 4. Jembatan Menuju ke Pulo Cinta

Sumber: Dokumentasi Peneliti 2020

Dari gambar diatas terlihat adanya jembatan yang merupakan dermaga yang terletak di Desa Patoameme sebagai satu satunya akses untuk menuju ke Pulo Cinta yang sebelumnya tidak ada. Jembatan tersebut dibangun menggunakan dana BUMDes, namun diinisiasi oleh stake holder setempat dan juga pihak Pulo Cinta Eco Resort, demi mempermudah akses bagi wisatawan yang datang.

\section{Output Negatif}

1. Adanya konflik stakeholder dengan LSM

2. Mulai adanya perubahan dialeg dan juga bahasa lokal yang digunakan anak muda setempat

\section{Bentuk dan Proses perubahan sosial masyarakat lokal pasca adanya pengembangan kawasan wisata pulo cinta eco resort}

1. Bentuk Perubahan Sosial Budaya

Perubahan sosial sosial mencakup unsur-unsur kebudayaan baik yang bersifat materiil dan atau yang immaterial dengan tetap menitikberatkan pada pengaruh besar dari unsur-unsur kebudayaan yang materiil dibandingkan immaterial (William 
F. Ogburn dalam Lauer, 1993). Elemen atau bentuk Sosial Budaya menurut John J. Macionis, 2009) yaitu:

\section{Simbol}

Manusia mentransformasikan dunia sekitarnya menjadi semesta simbol. Manusia tidak sekedar mengalami dunia di sekitarnya sebagaimana makhluk lain tetapi ia juga merubahnya menjadi penuh makna. Semua yang dilihat, dialami dan dirasakan manusia, oleh individu akan memiliki makna-makna tersendiri. Proses memahami makna ini mungkin terjadi dengan perantaraan simbol- simbol. Simbolsimbol yang muncul pada masyarakat Desa Patoameme sejak adanya kawasan wisata Pulo Cinta Eco Resort adalah simbol yang dimunculkan/ditimbulkan beberapa ormas Kabupaten Boalemo dan beberapa LSM yang tidak menyukai adanya Pulo Cinta eco resort dikarenakan bertentangan dengan apa yang diinginkan oleh ormas maupun LSM ini. Pulo cinta sendiri adalah kawasan wisata yang target marketnya adalah wisatawan asing, dimana yang ditakutkan oleh LSM dan ormas islam ini adalah akan adanya pergeseran kebudayaan. Namun, hal yang ditakutkan tersebut tidak terjadi, karena sampai saat ini acara-acara kebudayaan dan keagamaan di desa patoameme juga masih berjalan seperti sebelum adanya Pulo Cinta. Hanya saja penigkatan jumlah kunjungan wisatawan asing yang melonjak kemudian membuat adanya ke khawatiran dari Pihak LSM. Jumlah wisatawan asing dan domestik selama empat tahun belakangan dapat dilihat pada tabel dibawah ini. 
Tabel 5. Jumlah Kunjungan Wisatawan ke Pulo Cinta

\begin{tabular}{lcccc}
\hline No & Tahun & \multicolumn{2}{c}{ Kunjungan Wisatawan } & Total \\
& \multicolumn{5}{c}{ Wisatawan Domestik } & Wisatawan Asing & \\
\hline 1 & 2016 & 110 orang & 322 orang & 432 orang \\
2 & 2017 & 378 orang & 573 orang & 951 orang \\
3 & 2018 & 521 orang & 698 orang & 1.219 orang \\
4 & 2019 & 589 orang & 823 orang & 1.412 orang
\end{tabular}

Sumber: Management Pulo Cinta (2019)

Dari tabel tersebut terlihat bahwa adanya lonjakan kunjungan wisatawan ke Pulo Cinta, hanya saja dominasi wisatawan asing jauh lebih banyak dari wisatawan lokal yang datang. Hal ini karena sejak awal target wisatawan Pulo Cinta sendiri adalah wisatawan asing. Melonjaknya wisatawan asing yang datang ke Desa Patoememe kemudian membuat LSM Lokal DAN Ormas mengkawatirkan akan adanya perubahan pada norma masyarakat, padahal tersebut sama sekali tidak terjadi, hal tersebut juga ditekankan oleh Kepala Desa dan beberapa masyarakat lokal Patoameme bahwa saat ini kegiatan kegamaan masih rutin dilakukan.

\section{Bahasa}

Bahasa merupakan perwujudan paling penting dari simbol. Bahasa menggambarkan karakteristik budaya yang berkembang pada satu wilayah tertentu. Bahasa merupakan sistem simbol yang digunakan oleh manusia untuk berkomunikasi satu sama lain. Sejak adanya kawasan Pulo Cinta Eco Resort terdapat perbedaan logat dan modifikasi bahasa yang digunakan oleh kalangan anak muda di 
Desa Patoameme. Pihak Pulo cinta juga memberikan pelatihan bahasa inggris kepada karyawan mereka yang berasal dari Desa Patoameme, hal tersebut dilakukan agar mereka mampu berkomunikasi dengan wisatawan asing yang datang ke Pulo Cinta.

\section{Nilai}

Nilai merupakan salah satu elemen penting kebudayaan yang mengatur kehidupan manusia. Nilai berbicara tentang apa yang oleh manusia dipandang berharga atau terhormat yang kemudian menjadi pedoman hidup manusia. Nilai merupakan standard yang bersifat abstrak, yang dengannya, manusia menentukan apa yang dipandang baik dan buruk. Nilai nilai yang diterapkan di Desa Patoameme sebelum dan sesudah adanya Pulo Cinta eco resort adalah "Adat Bersendikan Sara, Sara Bersendikan Qitabullah" yaitu adat yang berdasarkan syariat, syariat yang berdasarkan Kitab (Alqur-an) sampai saat ini acara-acara kegaaaman (keislaman) masih berlangsung dan dipegang oleh masyarakat Desa Patoameme.

\section{Norma}

Norma lebih kongkret dari nilai. Norma menunjuk pada aturan berperilaku. Kalau diibaratkan dengan sebuah permainan, norma adalah aturan main yang diterapkan dalam sebuah permainan agar dapat berjalan sesuai apa yang diinginkan bersama. Norma yang ada di Desa Patoameme sudah di bicarakan dengan pihak Pulo cinta pada saat adanya pembangunan kawasan wisata Pulo Cinta Eco Resort, hal ini dilakukan karena target wisatawan di Pulo Cinta adalah wisatawan asing dan wisatawan domestic, maka tokoh-tokoh adat meminta pihak Pulo Cinta melakukan pembinaan kepada para turis asing yang hendak berwisata ke Pulo Cinta. Pembinaan tersebut ditujukan untuk menghormati nilai dan norma yang dianut oleh masyarakat Desa Patoameme. 
2. Proses Perubahan Sosial Budaya

Pulo Cinta adalah sebuah delta ditengah laut yang kemudian dijadikan tempat wisata oleh beberapa pengusaha atas inisiasi dari Bupati Kabupaten Boalemo, kemudian berdirilah Pulo Cinta Eco Resort yang memiliki 15 Kamar Cottage dengan jarak dari demaga adalah 25 menit dari Desa Patoameme atau Desa Masyarakat Lokal. Sebagaimana proses perubahan sosial budaya menurut Soekanto (2008) dimana, terdapat tiga tahapan perubahan sosial budaya masyarakat, yakni: 1) Penyesuaian masyarakat dari perubahan itu sendiri, 2) Saluran Perubahan Sosial dan kebudayaan, 3) Persepsi Masyarakat Lokal Desa Patoameme terhadap adanya Pulo Cinta Eco Resot dan juga wisatawan. masyarakat lokal yang sebelumnya bukan berasal dari daerah atau lokasi pariwisata tentunya mengalami proses perubahan. Seperti cara pandang masyarakat terhadap wisatawan, hal-hal atau potensi sumber apa saja yang seharusnya dapat dikembangkan demi memperoleh penghasilan dari adanya lokasi wisata dan bahkan cara bersosialisasi dengan orang asing. Sikap masyarakat lokal yang sebelumnya tertutup, perlahan mulai berubah menjadi terbuka setelah mereka memperoleh dampak yang baik dari adanya pengembangan kawasan wisata pulo cinta.

\section{Faktor- faktor yang mempengaruhi perubahan sosial budaya}

Faktor penyebab adanya perubahan sosial budaya masyarakat lokal Desa Patoameme sejak adanya Pulo Cinta Eco Resort yaitu:

1. Faktor dari dalam masyarakat lokal

Cara menerima dan juga sikap masyarakat lokal Desa Patoameme yang mudah menerima perubahan dan pemenuhan atas perbaikan ekonomi mereka setelah adanya kawasan pariwisata Pulo Cinta Eco Resort. 
2. Faktor dari luar masyarakat

Pengaruh penggunaan bahasa asing dan juga dialeg yang berbeda dari bahasa sehari-hari masyarakat lokal, serta pengaruh dari jenis kebudayaan lain yang berasal dari kebudayaan wisatawan yang banyak datang dari daerah perkotaan.

\section{Penutup}

Keadaan masyarakat lokal Desa Patoameme yang mengalami perubahan sosial budaya pasca adanya pengembangan Kawasan Wisata Pulo Cinta Eco Resort dari segi perubahan mata pencaharian yang ebelumnya mayoritas sebagai nelayan kini menjadi pengemudi taksi perahu. Adanya smber-sumber mata pencaharian baru, seperti usaha laundry dan menjadi staf di Pulo Cinta. rendahnya tingkat pendidikan juga sebelumnya cukup tinggi, hingga pada saat ini keinginan dan kemampuan masyarakat untuk memperoleh kehidupan yang yang lebih baik melalui keinginan untuk bersekolah sudah cukup tinggi. Minimnya pemahaman masyarakat terkait pemanfataan potensi sumber pun juga mulai berkembang, hal ini dibuktikan dengan ibu-ibu PKK yang sejak adanya Pulo Cinta muali membuat souvenir untuk kemudian dapat dijual sebagai oleholeh khas Pulo Cinta.

Bentuk perubahan sosial budaya yang muncul yaitu; a) simbol, dimana Proses memahami makna ini mungkin terjadi dengan perantaraan simbol-simbol. Simbolsimbol yang muncul pada masyarakat Desa Patoameme sejak adanya kawasan wisata Pulo Cinta Eco Resort adalah simbol yang dimunculkan/ditimbulkan beberapa ormas Kabupaten Boalemo dan beberapa LSM yang tidak menyukai adanya Pulo Cinta eco resort dikarenakan bertentangan dengan apa yang diinginkan oleh ormas maupun LSM ini. b) bahasa, dimana sejak adanya kawasan Pulo Cinta Eco Resort terdapat perbedaan logat dan modifikasi bahasa yang digunakan oleh kalangan anak muda di Desa Patoameme. Pihak Pulo cinta juga memberikan pelatihan bahasa inggris kepada 
karyawan mereka yang berasal dari Desa Patoameme, hal tersebut dilakukan agar mereka mampu berkomunikasi dengan wisatawan asing yang datang ke Pulo Cinta. c) Nilai, yakni Nilai nilai yang diterapkan di Desa Patoameme sebelum dan sesudah adanya Pulo Cinta eco resort adalah "Adat Bersendikan Sara, Sara Bersendikan Qitabullah" yaitu adat yang berdasarkan syariat, syariat yang berdasarkan Kitab (Alqur-an) sampai saat ini acara-acara kegaaaman (keislaman) masih berlangsung dan dipegang oleh masyarakat Desa Patoameme, dan d) Norma yang terlihat yaitu Norma yang ada di Desa Patoameme sudah di bicarakan dengan pihak Pulo cinta pada saat adanya pembangunan kawasan wisata Pulo Cinta Eco Resort, hal ini dilakukan karena target wisatawan di Pulo Cinta adalah wisatawan asing dan wisatawan domestic, maka tokoh-tokoh adat meminta pihak Pulo Cinta melakukan pembinaan kepada para turis asing yang hendak berwisata ke Pulo Cinta.

\section{Daftar Pustaka}

Akasara Horton, P. B. dan Hunt, C. L. 1992. Sosiologi Jilid 2. Jakarta: Erlangga.

Annisya Rakha Anandhyta dan Rilus A. Kinseng. 2020. "Hubungan Tingkat Partisipasi dengan TingkatKesejahteraan Masyarakat dalam Pengembangan Wisata Pesisir". Jurnal Nasional Pariwisata (JNP) UGM, Vol. 12(2) 1412- 9862.

Creswell W. John. 2013. Research Design Pendekatan Kualitatif, Kuantitatif, dan Mixed. Yogyakarta: Pustaka Pelajar.

Hadari, Nawawi. 2003. Metode Penelitian Bidang Sosial. Gajah Mada University Press, Yogyakarta.

Hanifah Gunawan, Karim Suryadi dan Elly Malihah. 2015. “Analisis perubahan Sosial Budaya Masyarakat Desa Cihideung Sebagai Desa Wisata". Sosietas Jurnal Pendidikan Sosiologi UPI, Vol. 5(2) 2528-4657.

Herimanto dan Winarno. 2009. Ilmu Sosial E Budaya Dasar. Jakarta. PT. Bumi Akasara. Macionis, John J. 2009. Society: The Basic. New Jersey: Pearson Education.

P. B. dan Hunt, C. L. 1992. Sosiologi Jilid 2. Jakarta: Erlangga.

Ranjabar Jacobus. 2014. Perubahan Sosial. Bandung: Alfabeta.

Robert Lauer H. 1993. Perspektif Tentang Perubahan Sosial. Jakarta: Rineka Cipta. 
Soedarso, Much Nurif dan Windiani. 2014. "Potensi dan Kendala pengembangan Pariwisata Berbasis Kekayaan Alam dengan Pendekatan Marketing Places (Studi Kasus Pengembangan Pariwisata di Bojonegoro)". Jurnal Sosial Humaniora (JSH) ITS, Vol 7(2) 1979-5521.

Soekanto Soerjono. 2000. Sosiologi Suatu Pengantar. Jakarta. PT Raja Grafindo Persada. Soerjono, Soekanto, 2008, Fungsi Hukum Dan Perubahan Sosial, Bandung: Alumni.

Yin, R. K. (2009). “Case Study Research: Design and Method” (4rd ed.). California: Sage Publications, Inc.

Undang-Undang nomor 10 Tahun 2009 tentang kepariwisataan.

\section{Profil Penulis}

Annisa Rizqa Alamri S.ST., M.A, adalah Dosen di Fakultas Ilmu Sosial dan Ilmu Politik Universitas Gorontalo. Ia menyelesaikan program D-IV di Sekolah Tinggi Kesejahteraan Sosial Bandung pada Tahun 2014, dan menyelesaikan program Magister Pembangunan Sosial dan Kesejahteraan di Fakultas Ilmu Sosial dan Ilmu Politik, Universitas Gadjah Mada pada Tahun 2015. Selain mengajar, Annisa juga sebagai Asesor di Lembaga Sertifikasi Profesi Pekerjaan Sosial (LSPS) Kementerian Sosial Republik Indonesia sejak 2018- sekarang.

Yayan Hanapi SH., MH adalah Dosen di Fakultas Hukum Universitas Gorontalo. Ia menamatkan pendidikan sarjana Hukum di Universitas Gorontalo pada tahun 2011 dan menamatkan Magister Hukum di Universitas Muslim Indonesia. Selain aktiv mengajar, Yayan juga tergabung dalam keanggotaan LBH Universitas Gorontalo sejak tahun 2018 hingga sekarang. 